\title{
Study on soil pollution caused by heavy metals in coal mining areas and vegetation restoration in surrounding areas
}

Xun Wang ( $\nabla$ xunhao95979853485@163.com )

Guizhou Qiansen Hi-tech Agricultural Biotechnology Development Co., LTD.

Research

Keywords: soil pollution, vegetation restoration, coal mining area, heavy metal, Populus L.

Posted Date: April 6th, 2021

DOI: https://doi.org/10.21203/rs.3.rs-360154/v1

License: (c) (1) This work is licensed under a Creative Commons Attribution 4.0 International License.

Read Full License 
Study on soil pollution caused by heavy metals in coal mining areas and vegetation restoration in surrounding areas

Xun Wang

Guizhou Qiansen Hi-tech Agricultural Biotechnology Development Co., LTD., Guiyang, Guizhou 550081, China

Corresponding address: Guanshan Zuoan Community, No. 101, Lincheng East Road, Guanshanhu District, Guiyang, Guizhou 550081, China

Email: xunhao95979853485@163.com

\section{Abstract:}

In this study, taking a coal mining area as an example, three vegetation restoration modes were designed: Populus L., Ligustrum lucidum Ait., and Amygdalus persica L., and soil and plant samples were collected to determine and evaluate the heavy metals. It was found that all the three modes were effective in eliminating heavy metal pollution in the soil, especially Populus L. and Ligustrum lucidum Ait:; in the soil layer at a depth of $0-20 \mathrm{~cm}$, the content of Cd was the lowest $(2.68 \mathrm{mg} / \mathrm{kg})$ in Populus L., and the content of $\mathrm{Cr}$ and $\mathrm{Pb}$ was the lowest $(58.64 \mathrm{mg} / \mathrm{kg}$ and $95.36 \mathrm{mg} / \mathrm{kg}$ ) in Ligustrum lucidum Ait., which was significantly lower than that in the bare land. The evaluation 
results demonstrated that the pollution under Populus L. and Ligustrum lucidum Ait. modes was moderate. In the aspect of the heavy metal content in plants, the content of Cd was the lowest, and the content of $\mathrm{Cr}$ and $\mathrm{Pb}$ was high. In the same plant, the content of heavy metals in the leaf was the lowest, followed by the stem and root. The experimental results show that the vegetation restoration mode can relieve the heavy metal pollution, which makes some contributions to solve the ecological restoration problem in coal mining areas.

Keywords: soil pollution, vegetation restoration, coal mining area, heavy metal, Populus L.

\section{Introduction}

Coal mine is an important resource for social development, which has very important economic value [1]. It is distributed in China widely but unevenly, and it concentrates in areas with a fragile ecological environment in Northwest China [2]. In addition, a series of changes caused by coal mining, such as soil loss, vegetation damage, etc., often aggravate the deterioration of the environment [3]. The destruction of the ecological environment by coal mining and the reconstruction of mining areas have been widely concerned by researchers. After coal mining, there are a large number of heavy metals in the accumulated waste, which will gradually pollute the soil and water source [4] and destroy the vegetation in the surrounding area. Reza et al. [5] studied the farmland around the Ledo coal mining area of Tinsukia district, Assam, India, and determined the content of $\mathrm{Cr}, \mathrm{Cd}, \mathrm{Ni}$, and $\mathrm{Pb}$ in 83 soil samples. They found high concentrations of heavy metals in low-lying paddy fields and near the coal mining site. Qin et al. [6] measured the concentrations 
of heavy metals in coal mining areas in Southwest Guizhou and found that the pollution levels of arsenic, mercury, and lead were high, showing a very high ecological risk level. Li et al. [7] studied the heavy metal pollution in a coal mining area in Henan Province and found that the content of $\mathrm{Cd}$, $\mathrm{Pb}, \mathrm{Cu}$, and $\mathrm{Zn}$ in the surface soil had exceeded the standard, showing a downward trend from the stone yard to the surrounding farmland. Li et al. [8] studied the heavy metal pollution of farmlands near coal mining areas, collected 24 soil samples, and simulated the leaching behavior of heavy metals under rainfall. The results showed that the risk of $\mathrm{Pb}$ was the highest, followed by $\mathrm{Cd}, \mathrm{Ni}$, $\mathrm{As}, \mathrm{Zn}, \mathrm{Cu}$, and $\mathrm{Cr}$, and the leaching rate of As was the highest under the simulated rainfall, followed by $\mathrm{Zn}, \mathrm{Ni}, \mathrm{Cd}, \mathrm{Cr}, \mathrm{Cu}$, and $\mathrm{Pb}$. This paper mainly analyzed the pollution of heavy metals to soils in coal mining areas. Taking a coal mining area as an example, this study designed three vegetation restoration models and analyzed the heavy metal pollution of soil and plants to find out the most suitable method for local ecological restoration.

\section{Methods}

\subsection{Overview of the study area}

The study area has a monsoon continental climate, with sufficient light and abundant rainfall. The soil types in the area include cinnamon soil, fluvo-aquic soil, etc. The coal resources are rich, and the reserves of limestone and granite are also high. Deciduous forest dominates. The main plants include Magnolia denudata Desr., Hibiscus syriacus Linn., Taraxacum mongolicum Hand.-Mazz., 
Typha angustifolia, etc. The coal quality of the studied coal mining area is coking-fat coal and gasfat coal, respectively.

\subsection{Research methods}

In $2010,1.2 \mathrm{hm}^{2}$ of land was selected from the study area for the vegetation restoration experiment, and $0.2 \mathrm{hm}^{2}$ of bare land was selected as the control plot. Three vegetation restoration modes were selected in the experimental site: Populus L., Ligustrum lucidum Ait., and Amygdalus persica $L$. Two-year-old tree species were selected. The vegetation status under the three modes was investigated in 2020, as shown in Table 1.

Table 1 Vegetation growth

\begin{tabular}{|c|c|c|c|}
\hline Mode & Populus L. & $\begin{array}{l}\text { Ligustrum lucidum } \\
\text { Ait. }\end{array}$ & Amygdalus persica $L$. \\
\hline Height/m & 12.07 & 6.78 & 4.01 \\
\hline $\begin{array}{l}\text { Diameter at breast } \\
\text { height } / \mathrm{cm}\end{array}$ & 13.27 & 8.68 & 5.33 \\
\hline $\begin{array}{l}\text { Row spacing }(\mathrm{m} \times \\
\mathrm{m})\end{array}$ & $4 \times 4$ & $3 \times 2$ & $2 \times 2$ \\
\hline Dominant herbs & $\begin{array}{l}\text { Portulaca oleracea L., } \\
\text { Cirsium setosum, etc. }\end{array}$ & $\begin{array}{l}\text { Cichorium endivia L., } \\
\text { Cirsium setosum, etc. }\end{array}$ & $\begin{array}{l}\text { Xanthium sibiricum } \\
\text { Patrin ex Widder, } \\
\text { Cirsium setosum, etc. }\end{array}$ \\
\hline
\end{tabular}


Soil samples under different modes were collected. Three points in each plot were randomly selected to calculate the average value of the time zone. Soil samples were collected at a depth of 0-20 $\mathrm{cm}$ and $20-40 \mathrm{~cm}$ of each sampling point. Each layer was repeatedly sampled three times, and then the soils were mixed evenly. In the sampling process, wooden or bamboo instruments were used to avoid exogenous metal pollution. Soil samples were also collected in the same way in the control plot. Under different modes, the roots, stems, and leaves of five normal plants were collected and brought back to the laboratory.

Impurities, such as plant residues, were removed from the soil samples. After natural drying, the soils were screened by a 20 -mesh nylon screen for subsequent index determination. The collected roots, stems, and leaves were divided, rinsed by deionized water, and dried in the air. After 30-min enzyme deactivation in a $105{ }^{\circ} \mathrm{C}$ oven, it was dried to the constant weight under $70{ }^{\circ} \mathrm{C}$ and screened by an 80 -mesh nylon screen.

\subsection{Determination of heavy metals}

Soil:

(1) $0.25 \mathrm{~g}$ of the soil that has been screened by a 100 -mesh sieve was put into a $50 \mathrm{~mL}$ polytetrafluoroethylene crucible, moistened with water, and added with $10 \mathrm{~mL}$ of concentrated hydrochloric acid. Then, it was heated by an electric furnace at a low temperature. When it was evaporated to $3 \mathrm{~mL}$, it was cooled, added with $5 \mathrm{~mL}$ of concentrated nitric acid, $5 \mathrm{~mL}$ of hydrofluoric acid, and $3 \mathrm{~mL}$ of perchloric acid, capped, and heated for one hour.

(2) After opening the cover, heating continued until the content became thick. 
(3) Digestion was repeated until white smoke was no longer produced and the content was thick. After cooling, it was moved to a $50 \mathrm{~mL}$ volumetric flask, added with $5 \mathrm{~mL}$ of lanthanum nitrate, and cooled. The content of $\mathrm{Cd}, \mathrm{Cr}$, and $\mathrm{Pb}$ was detected by atomic absorption spectrometry (AAS).

Plant:

$1 \mathrm{~g}$ of the plant was screened by a 100-mesh sieve, put into a crucible, and added with $20 \mathrm{~mL}$ of concentrated nitric acid. After soaking overnight, it was heated until the particles melt. 3-5 mL of perchloric acid was added for digestion, and heating continued after the yellow smoke was dispersed. The heating stopped when the solution became pink or light yellow. Then, it was dissolved by adding $1 \%$ nitric acid and filtered. Finally, the content of heavy metals was measured by the AAS method.

\subsection{Heavy metal pollution assessment}

(1) Single-factor index method: $P_{i}=\frac{C_{i}}{S_{i}}$, where $P_{i}$ stands for the accumulative index of heavy metal $i, C_{i}$ stands for the measured vale, and ${ }^{S_{i}}$ stands for the reference value of assessment. In this study, the soil background value of Shandong Province [9] is taken as the evaluation standard.

(2) Nemerow composite index method [10]: $P=\left(\frac{p_{\max }^{2}+p_{\text {ave }}^{2}}{2}\right)^{\frac{1}{2}}$, where $P$ represents the Nemerow composite index and $p_{\max }$ and $p_{\text {avg }}$ are the maximum and minimum values of the single index, respectively.

The evaluation results are shown in Table 2 . 
Table 2 Grade evaluation criteria

\begin{tabular}{|c|c|c|}
\hline \multirow[t]{2}{*}{ Grade } & \multicolumn{2}{|c|}{ Single-factor index method } \\
\hline & Index value & Status \\
\hline 1 & $P_{i}<1$ & Safe \\
\hline 2 & $1 \leq P_{i} \leq 2$ & Mild accumulation \\
\hline 3 & $2 \leq P_{i} \leq 3$ & Moderate accumulation \\
\hline 4 & $P_{i} \geq 3$ & Severe accumulation \\
\hline 5 & - & - \\
\hline \multirow[t]{2}{*}{ Grade } & \multicolumn{2}{|c|}{ Nemerow composite index method } \\
\hline & Index value & Status \\
\hline 1 & $P \leq 0.7$ & Safe \\
\hline 2 & $0.7<P \leq 1$ & Alert \\
\hline 3 & $1<P \leq 2$ & Mild accumulation \\
\hline 4 & $2<P \leq 3$ & Moderate accumulation \\
\hline 5 & $P>3$ & Severe accumulation \\
\hline
\end{tabular}

\section{Results}

\subsection{Heavy metal pollution in soil}

It was seen from Table 3 that different vegetation restoration models had different effects.

From the perspective of $\mathrm{Cd}$, in the soil layer at a depth of $0-20 \mathrm{~cm}$, the $\mathrm{Cd}$ content in Populus L. was 
the lowest, which was $57.39 \%$ of the bare land; in the soil layer at a depth of $20-40 \mathrm{~cm}$, the reduction effect of Populus L. on Cd was the most obvious, which was $72.48 \%$ of the bare land. From the perspective of $\mathrm{Cr}$, in the soil layer at a depth of 0-20 cm, Ligustrum lucidum Ait. had the most significant reduction effect; the content of $\mathrm{Cr}$ in the bare land was $97.36 \mathrm{mg} / \mathrm{kg}$, while the content of $\mathrm{Cr}$ under the mode of Ligustrum lucidum Ait. was $58.64 \mathrm{mg} / \mathrm{kg}$, which was $39.77 \%$ lower than that of the bare land. With the increase of the depth of the soil layer, the $\mathrm{Cr}$ content decreased under the three modes. The $\mathrm{Cr}$ content under the mode of Populus L. was the lowest, which was 52.15\%, followed by Ligustrum lucidum Ait. and Amygdalus persica L. From the perspective of $\mathrm{Pb}$, in the soil layer at a depth of $0-20 \mathrm{~cm}$, the $\mathrm{Pb}$ content in the bare land was $148.65 \mathrm{mg} / \mathrm{kg}$; the content of $\mathrm{Pb}$ was the highest under the mode of Amygdalus persica L., followed by Populus L. and Ligustrum lucidum Ait., and the content of $\mathrm{Pb}$ under the mode of Ligustrum lucidum Ait. was $35.85 \%$ lower than that in the bare land. In the soil layer at a depth of $20-40 \mathrm{~cm}$, the content of $\mathrm{Pb}$ under three modes was significantly lower than that in the bare land, and the content of $\mathrm{Pb}$ under the mode of Populus L.was the lowest, which was $37.59 \%$ of the bare land.

Table 3 Content of heavy metals in soil $(\mathrm{mg} / \mathrm{kg})$

\begin{tabular}{|l|l|l|l|l|l|}
\hline \multirow{2}{*}{$\begin{array}{l}\text { Soil } \\
\text { layer }\end{array}$} & Element & Bare land & Populus L. & Ligustrum & Amygdalus \\
lucidum Ait. & persica L. \\
\hline $0-20 \mathrm{~cm}$ & $\mathrm{Cd}$ & 4.67 & 2.68 & 3.12 & 4.08 \\
\cline { 2 - 6 } & $\mathrm{Cr}$ & 97.36 & 94.27 & 58.64 & 72.77 \\
\cline { 2 - 6 } & $\mathrm{Pb}$ & 148.65 & 97.55 & 95.36 & 102.86 \\
\hline
\end{tabular}




\begin{tabular}{|l|l|l|l|l|l|}
\hline \multirow{2}{*}{$\mathrm{cm}-40$} & Element & Bare land & Populus L. & $\begin{array}{l}\text { Ligustrum } \\
\text { lucidum Ait. }\end{array}$ & $\begin{array}{l}\text { Amygdalus } \\
\text { persica L. }\end{array}$ \\
\cline { 2 - 6 } & $\mathrm{Cd}$ & 5.96 & 4.32 & 4.87 & 5.12 \\
\cline { 2 - 6 } & $\mathrm{Cr}$ & 77.39 & 40.36 & 56.27 & 57.12 \\
\cline { 2 - 6 } & $\mathrm{Pb}$ & 201.25 & 75.64 & 113.27 & 100.55 \\
\hline
\end{tabular}

Table 4 shows that the evaluation result of soil heavy metal pollution in the bare land without vegetation restoration was severe, which indicated that the soil in this area had been seriously polluted by heavy metals under the influence of mining. In the soil layer at a depth of $0-20 \mathrm{~cm}$, the effects under the modes of Populus L. and Ligustrum lucidum Ait. were good, and the pollution evaluation level was moderate. In the soil layer at a depth of $20-40 \mathrm{~cm}$, the pollution under the three modes was moderate, showing good effects.

Table 4 Evaluation results

\begin{tabular}{|c|c|c|c|c|c|c|}
\hline Soil layer & Evaluation method & & Bare land & $\begin{array}{l}\text { Populus } \\
\text { L. }\end{array}$ & $\begin{array}{l}\text { Ligustru } \\
\text { m } \\
\text { lucidum } \\
\text { Ait. }\end{array}$ & $\begin{array}{l}\text { Amygdalus } \\
\text { persica L. }\end{array}$ \\
\hline \multirow[t]{3}{*}{$0-20 \mathrm{~cm}$} & \multirow[t]{3}{*}{ Single-factor index } & $\mathrm{Cd}$ & Severe & Severe & Severe & Severe \\
\hline & & $\mathrm{Cr}$ & Severe & Severe & Moderate & Severe \\
\hline & & $\mathrm{Pb}$ & Severe & Moderate & Severe & Severe \\
\hline
\end{tabular}




\begin{tabular}{|l|l|l|l|l|l|l|}
\hline & \multicolumn{2}{|l|}{ Nemerow composite index } & Severe & Moderate & Moderate & Severe \\
\hline 20-40 cm & Single-factor index & $\mathrm{Cd}$ & Severe & Severe & Severe & Severe \\
\cline { 3 - 7 } & & $\mathrm{Cr}$ & Severe & Mild & Moderate & Moderate \\
\cline { 3 - 7 } & & $\mathrm{Pb}$ & Severe & Mild & Moderate & Severe \\
\cline { 3 - 7 } & & & & & & \\
\cline { 3 - 7 } & Nemerow composite index & Severe & Moderate & Moderate & Moderate \\
\hline
\end{tabular}

\subsection{Heavy metal pollution in plants}

The content of heavy metals in plants under different modes is shown in Table 5.

It was seen from Table 5 that the content of heavy metals in plants showed similar characteristics: the content of heavy metals in leaves was lower than that in stems, and the highest content was in the roots of plants. The difference between different patterns was small. In general, the content of $\mathrm{Cr}$ was the highest, followed by $\mathrm{Pb}$ and $\mathrm{Cd}$. Based on Tables 3 and 5, it was also found that the content of $\mathrm{Cr}$ and $\mathrm{Pb}$ in the soil was high, while the content of $\mathrm{Cd}$ was low; therefore, it showed similar accumulation characteristics in plants. $\mathrm{Cd}$ is a non-essential element for plant growth but also has strong toxicity. Under normal circumstances, the content of $\mathrm{Cd}$ in plants is 0.05 $0.2 \mathrm{mg} / \mathrm{kg}$. When the content is too high, it will not only affect the growth of plants but also easily enter the human body under the action of the food chain due to the strong mobility of $\mathrm{Cd}$. $\mathrm{Cr}$ is a necessary element for plant growth, but it will also have a negative effect when it is excessive. The content of $\mathrm{Pb}$ in plants is $0.1-10 \mathrm{mg} / \mathrm{kg}$; when it is excessive, it has strong toxicity. It is found that heavy metal pollution in soils also has a huge impact on plants. 
Table 5 Content of heavy metals in plants $(\mathrm{mg} / \mathrm{kg})$

\begin{tabular}{|c|c|c|c|c|}
\hline Soil layer & Element & Populus L. & $\begin{array}{l}\text { Ligustrum } \\
\text { lucidum Ait. }\end{array}$ & $\begin{array}{l}\text { Amygdalus } \\
\text { persica } L .\end{array}$ \\
\hline \multirow[t]{3}{*}{ Leaf } & $\mathrm{Cd}$ & 0.27 & 0.23 & 0.02 \\
\hline & $\mathrm{Cr}$ & 11.33 & 11.29 & 10.89 \\
\hline & $\mathrm{Pb}$ & 5.68 & 6.42 & 3.64 \\
\hline Layer & Element & Populus L. & $\begin{array}{l}\text { Ligustrum } \\
\text { lucidum Ait. }\end{array}$ & $\begin{array}{l}\text { Amygdalus } \\
\text { persica } L .\end{array}$ \\
\hline \multirow[t]{3}{*}{ Stem } & $\mathrm{Cd}$ & 0.06 & 0.03 & 0.01 \\
\hline & $\mathrm{Cr}$ & 12.07 & 12.16 & 11.36 \\
\hline & $\mathrm{Pb}$ & 8.67 & 11.22 & 5.74 \\
\hline Layer & Element & Populus L. & $\begin{array}{l}\text { Ligustrum } \\
\text { lucidum Ait. }\end{array}$ & $\begin{array}{l}\text { Amygdalus } \\
\text { persica } L .\end{array}$ \\
\hline \multirow[t]{3}{*}{ Root } & $\mathrm{Cd}$ & 1.67 & 1.33 & 0.89 \\
\hline & $\mathrm{Cr}$ & 70.66 & 75.66 & 77.96 \\
\hline & $\mathrm{Pb}$ & 41.36 & 43.67 & 32.14 \\
\hline
\end{tabular}

\section{Discussion}

In mining, the surface morphology of the land in the coal mining area will change greatly. The destruction of the land is manifested in three forms: excavation, collapse, and occupation, which 
will cause land subsidence [11], nutrient loss, land desertification and drying, and land occupation, further aggravating the contradiction between people and land. For the vegetation in the coal mining area, due to the destruction of land, the growth of vegetation decreases [12], and soil erosion [13, 14] and desertification are intensified. In the process of mining, a large amount of mine water and waste water will pollute the local rivers and waters [15]. The waste gas produced by coal gangue spontaneous combustion not only pollutes the atmospheric environment [16] but also harms human health. Under the action of precipitation and spontaneous combustion, heavy metal elements in coal gangue will transfer to affect the surrounding soil and water source. The heavy metals accumulated in a large number of animals and plants will migrate to the human body [17], seriously threatening human health. At present, the methods of ecological restoration include: (1) performing harmless treatment on mine water and coal gangue, treating waste water by electrodialysis and lime neutralization [18], and recycling coal gangue; (2) preventing dust in open-pit mine and drainage and utilize coalbed methane; (3) reclaiming mining land to improve soil; (4) selecting excellent plant species to recover vegetation [19]; (4) strengthening construction of forest and grassland [20] to bring soil erosion under control.

In this paper, the heavy metal pollution in coal mining areas was studied, and the effects of different vegetation restoration models were analyzed. It was found from the results that all the vegetation restoration models could reduce heavy metals and had different performances in different soil layers. It was seen from Table 3 that Populus $L$. had the best reduction effect on Cd; compared with bare land, the content of $\mathrm{Cd}$ in the soil was the lowest. For $\mathrm{Cr}$, all the three models had good reduction effects; the content of $\mathrm{Cr}$ in the soil at different depths was similar under the mode of Ligustrum lucidum Ait., and the content of $\mathrm{Cr}$ in the soil layer at a depth of $20-40 \mathrm{~cm}$ under the mode 
of Populus L. was $52.15 \%$ that of the bare land, showing the most significant reduction. The content of $\mathrm{Pb}$ decreased under the three modes, but the mode of Populus $L$. had the best effect.

It was found from the evaluation results of heavy metal pollution (Table 4) that the soil heavy metal pollution in the study area was relatively serious, which has been improved under the effect of different vegetation restoration modes. Among the three modes, the restoration effects of Populus L., Ligustrum lucidum Ait. were good. There were some differences in the content of heavy metals in different parts of plants, and the content of heavy metals in leaves was the lowest, followed by stems and roots; the content of $\mathrm{Cr}$ and $\mathrm{Pb}$ was high, and the content of $\mathrm{Cd}$ was relatively low.

In this paper, the heavy metal pollution in coal mining areas has been studied. Although some achievements have been made, there are still some shortcomings. In future works,

(1) the physical properties and biological status of the soil should be further analyzed;

(2) more vegetation restoration models should be compared;

(3) more in-depth studies on ecological restoration of coal mining area should be studied.

\section{Conclusion}

This study analyzed the heavy metal pollution in coal mining areas and the content of heavy metals in soils and plants under different vegetation restoration modes. It was found that Populus L. and Ligustrum lucidum Ait. could significantly reduce heavy metals in soils. The content of heavy metals was the highest in leaves, followed by stems and roots. The content of $\mathrm{Cr}$ and $\mathrm{Pb}$ was high, similar to the situation in the soil. According to the research results, two vegetation restoration 
modes, Populus L. and Amygdalus persica L., can be used in restoring the ecological environment of the study area to promote the environmental recovery of the surrounding area.

\section{Declarations}

Availability of data and materials

The data that support the findings of this study are available from the corresponding author upon reasonable request.

Conflicts of interest

The authors declare no conflict of interests.

Funding

No funding received.

Authors' contributions

XW designed research, performed research, analyzed data, and wrote the paper.

Acknowledgements 
Not applicable

\section{References}

[1] Zhang G, Yuan X, Wang K. Biodiversity and temporal patterns of macrozoobenthos in a coal mining subsidence area in North China. PeerJ, 2019, 7(2):e6456.

[2] Hou H, Ding Z, Zhang S, Guo S, Yang Y, Chen Z, Mi J, Wang X. Spatial estimate of ecological and environmental damage in an underground coal mining area on the Loess Plateau: Implications for planning restoration interventions. Journal of Cleaner Production, 2020, 287(1):125061.

[3] Shi XM. Factors Influencing the Environmental Satisfaction of Local Residents in the Coal Mining Area, China. Social Indicators Research, 2015, 120(1):67-77.

[4] Mohanty A K, Lingaswamy M, Rao V G, Sankaran S. Impact of acid mine drainage and hydrogeochemical studies in a part of Rajrappa coal mining area of Ramgarh District, Jharkhand State of India. Groundwater for Sustainable Development, 2018:164-175.

[5] Reza S K, Baruah U, Singh S K, Das TH. Geostatistical and multivariate analysis of soil heavy metal contamination near coal mining area, Northeastern India. Environmental Earth Sciences, 2015, 73(9):5425-5433.

[6] Qin F X, Wei C F, Zhong S Q, Huang XF, Pang WP, Jiang X. Soil heavy metal(loid)s and risk assessment in vicinity of a coal mining area from southwest Guizhou, China. Journal of Central South University, 2016, 23(9):2205-2213. 
[7] Li K, Gu Y, Li M, Zhao L, Ding J, Lun Z, Tian W. Spatial analysis, source identification and risk assessment of heavy metals in a coal mining area in Henan, Central China. International Biodeterioration \& Biodegradation, 2017:S0964830517304766.

[8] Li H, Xu W, Dai M, Wang ZW, Dong XJ, Fang T. Assessing heavy metal pollution in paddy soil from coal mining area, Anhui, China. Environmental Monitoring and Assessment, 2019, 191(8):518-

[9] Pang XG, Dai JR, Hu XP, Song ZY, Yu C, Chen L, Zhang HP, Liu HF, Wang HJ, Wang ZH, Zhao XQ, Zeng XD, Ren WK. Soil Geochemical Background Values in Shandong Province . Land and Resources in Shandong Province, 2018, 34(1):39-43.

[10] Zhang ZY, Yang XD, Yang ST. Heavy metal pollution assessment, source identification, and health risk evaluation in Aibi Lake of northwest China. Environmental Monitoring and Assessment, 2018, 190(2):69.

[11] Zhou D W, Wu K, Cheng G L, Li L. Mechanism of mining subsidence in coal mining area with thick alluvium soil in China. Arabian Journal of Geosciences, 2015, 8(4):1855-1867.

[12] Yang X, Lei S, Zhao Y, Cheng W. Use of hyperspectral imagery to detect affected vegetation and heavy metal polluted areas: a coal mining area, China. Geocarto International, 2020(2):1-20.

[13] Zhao G, Wang H, Li J, Guo H. Study on Spatial Variation of Soil Moisture in Coal Mining Subsidence Area in Mu Us Sandy Land. Asian Agricultural Research, 2018, 10(03):70-74. 
[14] Qiao W, Li W, Li T, Chang J, Wang Q. Effects of Coal Mining on Shallow Water Resources in Semiarid Regions: A Case Study in the Shennan Mining Area, Shaanxi, China. Mine Water and the Environment, 2017, 36(1):104-113.

[15] He KQ, Guo L, Guo YY, Luo HL, Liang YP. Research on the effects of coal mining on the karst hydrogeological environment in Jiaozuo mining area, China. Environmental Geology, 2019, 78(15):434.1-434.13.

[16] Tang Z, Chai M, Cheng J, Jin J, Yang Y, Nie Z, Huang Q, Li Y. Contamination and health risks of heavy metals in street dust from a coal-mining city in eastern China. Ecotoxicology \& Environmental Safety, 2016, 138:83.

[17] Cheng J, Zhang X, Tang Z, Yang Y, Nie Z, Huang Q. Concentrations and human health implications of heavy metals in market foods from a Chinese coal-mining city. Environmental Toxicology and Pharmacology, 2017, 50:37.

[18] Dlamini N G, Basson A K, Pullabhotla V S R. Synthesis and Application of FeCu Bimetallic Nanoparticles in Coal Mine Wastewater Treatment. Minerals, 2021, 11(2):132.

[19] Li X, Gao J, Zhang J, Wang R, Jin L, Zhou H. Adaptive strategies to overcome challenges in vegetation restoration to coalmine wasteland in a frigid alpine setting. Catena, 2019, 182:104142.

[20] Nussbaumer Y, Cole M A, Offler C E, Patrick JW. Identifying and ameliorating nutrient limitations to reconstructing a forest ecosystem on mined land. Restoration Ecology, 2016, 24(2):202-211 